\title{
Marxist morphologies
}

A materialist critique of brute materialities, flat infrastructures, fuzzy property and complexified cities

Michat Murawski

Abstract: This article critiques assumptions made by urban anthropologists and other scholars of cities, focusing on currently fashionable theories of infrastructure, materiality, and complexity. It problematizes how scholarship informed by actor-network theory, assemblage theory and other varieties of (post)postmodernism uses morphological optics and metaphors to represent social life, the material world, and existence itself as necessarily "flat," "complex" or "fuzzy." As a corrective, it proposes reorienting our social morphologies with reference to a Marxist notion of infrastructure, founded on a dynamic understanding of the relationship between determining economic base and determined superstructure. It constructs its theoretical edifice with reference to the remaking of post-1945 Warsaw as a socialist city through property expropriation and monumental architectural and planning works, and post-1989 attempts to unmake its socialist character through property reprivatization and unplanning.

Keywords: architecture, assemblage, capitalism, infrastructure, Marxism, political economy, postsocialism, Warsaw

\section{Introduction: The morphological consensus}

What is the shape and form of the social world? What are its topographical, geometrical, aesthetic, and dynamic characteristics? How are these features-I will call them "morphological" features - understood and represented by scholars (and the people they study), in metaphorical as 
well as in actual terms?

This article critiques some morphologies of the social, which have become popular among anthropologists and other scholars of society and culture during recent years. In particular, I focus my attention on several morphological optics and framings, which frequently cluster together in ethnographic descriptions and theorizations. Chief among these are ideas that the social is inherently, or ought to be kept "flat"; that social things and processes never cohere into rigid "structures" but instead clump into transient and volatile "assemblages"; that causality is "emergent" (or nonlinear) rather than "effective" (or linear); and that the complexity of social life is "irreducible." 1

Ideas about social "flatness" and "complexity" are expressed with particular clarity and consistency in anthropological scholarship on cities, architecture, and material infrastructure. In the reigning mind-set of cutting-edge urban anthropological research, an assumed "flat" or "irreductionist" concept of the urban has become axiomatic. "No measure will ever wrench" from cities their "fundamental irreducibility," says the French sociologist Bruno Latour (2006: 85). Urban scholarship ought to shift "from an analytics of structure to an analytics of assemblage," writes Aihwa Ong (2011: 4). Unlike urban geographers and sociologists, who are tarnished by a "Marxist pedigree," anthropologists are particularly well placed to "account for the complexity of [urban-global] engagements rather than subject them to economistic or political reductionism" $(3) .^{2}$

Much recent anthropological scholarship on material infrastructure, likewise, is framed in a consciously flattening or complexifying idiom, and occasionally in explicitly anti-Marxist terms. Infrastructure, it is written, ought to be understood not in terms of its "material solidity" but in terms of its "flux and precarity" (Boyer 2014): not as a "system that appears to underline 
and give rise to the phenomenal world"- such as "Marxist analyses of base/superstructure" (Larkin 2013: 232) — but as an “irreducible plurality" (Harvey 2012: 77), a "fuzz concept," or a “socio-material assemblage” (Simone 2012). James Ferguson's afterword to a collection devoted to the anthropology of "infrastructural violence" is particularly explicit in its attempt to detach infrastructure from Marxian associations:

The "infra-structure" that is of interest here is clearly not conceived as "infra-structural" in the Marxian sense (underlying, causally primary), nor is it imagined as a "structure" in the structuralist sense. . . It is "infra" less in the sense of constituting a "base" than in the sense of a "swarming omnipresence" that is implied in Foucault's idea of "infra-power." (2012: 559)

The "underlying," "causally primary" Marxian model of infrastructure, which Ferguson rejects, constitutes, it is significant to note, an architectural metaphor: the original German terms Basis and $\ddot{U}$ berbau carry, unlike their English translations, explicitly architectural connotations. ${ }^{3}$ Its best-known formulation is delivered in the Preface to the Contribution of the Critique of Political Economy (Marx 1970: 11): "The sum total of these relations of production constitutes the economic structure of society, the real foundation, on which rises a legal and political superstructure to which correspond definite forms of social consciousness." As Marx and Engels themselves and subsequent Marxist theorists repeatedly made clear, this architectural metaphor is not absolute: it does not imply the total determination of the superstructure by the infrastructure, of the upper stories by the foundations. In Louis Althusser's (1969) explication, extrapolated from an analysis of Engels's letter to Joseph Bloch, the economic base is "determinant in the last 
instance," but it is at the same time "overdetermined" by a potentially endless, antagonistic myriad of superstructural factors acting reciprocally on the base, according to their own "relatively autonomous" dynamics. In Althusser's model, the entire "building" constitutes the "social whole," encompassing both base and superstructure; the foundations correspond to the base, and each superstructural upper floor possesses varying levels of "relative autonomy" and capacities for "reciprocal action" on the base (1971: 90-91).

The architectural metaphor - of society as a multistory edifice, dependent on the strength of its foundations-is pointedly rejected by the social flatteners. The best-known flattener, Latour, has argued that "modernist" understandings of social action—such as the Marxian basesuperstructure duality, the Freudian "topological" model of the psyche, or the Durkheimian social fact-mirror their pious predecessors in positioning causally more powerful or bigger entities at a morphological extremity "above or below the interactions" (2005: 177). In Latour's words, "angels and demons that had pushed and pulled our humble souls" have been replaced by "crowds, masses, statistical means, invisible hands and unconscious drives" (43). Latour advocates "keeping the social flat" (165-172) so that the irreducible, intricate heterogeneity of its constitutive elements is not drowned out by the deterministic reductivisms or inflationisms of "macro" or "infra"-centric social explanations. To illustrate his point, Latour deploys the construction site as a sort of anti-architectural metaphor: a terrain on which humans and nonhumans lie and scurry around, assembling and disconnecting to/from each other; on which is nothing is yet "standing" and "everything could still fail" (88-89). The messy horizontality of Latour's construction site pointedly resists the celestial panoramas and "God's eye-views" (see Certeau 1984) of the modernist demiurge. In Latour's own words: "No panorama enables us to 'capture all of Paris' in a single glance"; "No bird's eye view could ... capture the multiplicity 
of these places which add up to make the whole Paris" $(2006: 4,32)$.

One thing I seek to do in this article is to demonstrate the descriptive capacities of a vertical architectural metaphor, which makes room for complexity and heterogeneity, without rejecting a priori the possibility that some foundational, causally prior processes may originate in the base. This article, then, delves into the architectural metaphor, in order to contribute some ideas to how anthropologists — in particular, anthropologists of cities and infrastructure — might usefully deploy morphological optics, metaphors, and illustrations not only to elucidate the complexity of urban life but also to account for the structures and causalities, which undergird this complexity. As Jonathan Friedman has observed, with reference to the increased interest in fragmentation and disorder among scholars in the 1980s and 1990s, disorder ought not be interpreted neither as "chaos" nor as "entropy" (1993: 206). Disorder and complexity are, as Friedman points out, in fact, "systemic" and possessed of an "order of their own"—-an order that is, as is often forgotten by scholars today, fundamentally economic in character. As an alternative to the styles, shapes, and forms reigning in the discipline today, then, this article proposes exhuming a vertical optic_-founded on the Marxian dialectic between determining economic base or infrastructure and determined (political, ideological, legal, cultural) superstructure.

I develop my ideas toward a vertical, materialist morphology of the city with reference to the relationship between the Palace of Culture and Science (PKiN - Pałac Kultury i Nauki) —a Stalinist skyscraper "gifted" to Poland by the Soviet Union—and the contemporary city of Warsaw, whose center is dominated by the sprawling and towering palace. Briefly outlining the plot of a 1990s Polish crime series, I begin by laying out why I found a vertical architectural metaphor more useful for understanding the social life of the Palace of Culture and Science than 
a flat one.

Subsequently, I explore how the political-economic dynamics of Warsaw-PKiN relations revolve around the act of property expropriation, which accompanied the palace's "gifting" to the city, and the different trajectories for its reappropriation currently vying for dominance on the fragmented terrain of the postsocialist metropolis. During the communist era, I argue, the PKiN functioned as a radical tool for the reduction of the city's proprietorial complexity. After the fall of the Polish People's Republic in 1989, however, the palace—still vertical, still-socialist ${ }^{4}$ stands as a bulwark resisting the city's proprietorial, social, and morphological recomplexification.

In laying out my critique, I draw together and expand on several threads of what appears to be a gathering ennui with anthropology's morphological consensus. As Talia Dan-Cohen (2017: 1) has observed, "diagnoses of complexity" have "run rampant" in anthropology in recent years, and scholars are increasingly treating complexity as a "settled" or "ontological fact"—as an end point rather than as a starting point for anthropological inquiry. In a similar vein, Nikolai Ssorin-Chaikov has pointed out, "If we already know that things are complex, then we do not really need ethnography ... just to affirm that." Complexity, is, in Ssorin-Chaikov's words “always a good question but a bad answer" (2013: 16).

There may be more to the current morphological consensus, however, than a more or less random buildup of momentum around a particular way of seeing the world: there could, in fact, be a "macro" or "infra" explanation for the dominance of complexity and flatness in anthropology’s morphological imaginary. Vita Peacock points to the paradoxical co-temporality between the moment at which anthropologists flattened society, negating hierarchical ideas, and the moment at which new structural inequalities emerged globally "on an unprecedented scale" 
(2015: 3). Correspondingly, it is significant that the emergence of complexity and flatness as "dominant problematics" (Dan-Cohen 2017: 4) in anthropology and neighboring disciplines was contemporaneous with the relative marginalization of Marxism—in particular, of structural Marxism — from the anthropological mainstream from the late 1970s onward and from the retreat away from landed property—and its connection to hierarchies of status and mechanisms of social reproduction - as a core line of inquiry in economic anthropology. Property has continued to be a topic of interest for anthropologists, but it has become an increasingly deterritorialized concept, detached from land, real estate and "thingness" (Verdery and Humphrey 2004)—from the foundations, as it were — and consciously reassociated with a more flexible, relational, and intangible set of concerns: from custom (Leach 2003) to culture (Kaneff and King 2004; Anderson and Geismar 2017), from bodily or interpersonal "substance" (Strathern 1999) to intellectual property and biotechnology (Parry 2004). ${ }^{5}$

This is not to say that property-as-land has disappeared from anthropology altogether (see Fay and James 2008). The enormous proprietorial reconfigurations, which have accompanied decolonization, the rise and retreat of state socialism and welfare statism during the late twentieth and twenty-first centuries have received anthropological attention, in particular, from scholars of post-apartheid South Africa (Comaroff and Comaroff 1998; James 2007) and, especially extensively, postsocialist Eastern Europe (see, e.g., Buchowski 2006; Hann 1998, 2005; Humphrey 1998; Kaneff 1998; Sikor et al. 2017; Verdery 1999, 2003; Verdery and Humphrey 2004). Crucially, however, the overwhelming portion of this research has focused on rural land reform and restitution. Landed property, then, has somehow—with notable exceptions - remained the domain of the village anthropologist,${ }^{6}$ while anthropological inquiry into emergent forms of property has bypassed the built matter of the city, focusing instead on 
more abstract concerns located in the loftier reaches of the superstructure. This blind spot is all the more remarkable given the overwhelmingly urban character of almost all formerly socialist societies globally and given the fact that the urbanization of these societies - and the ensuing construction of socialist urbanity_constitutes one of state socialism's most consciously articulated projects and, from a purely quantitative perspective, one of its most tangible achievements (Murawski 2018).

The city_its architecture, infrastructure, and social life — constitutes the key site of the making and unmaking of socialism. The primary mechanism, which enabled the construction of the socialist city — and which determined its spatial and aesthetic parameters, as well as the forms of everyday life which inhabited it - was the deprivatization of the proprietorial structure of the city, which all state socialist regimes undertook, to a greater or lesser extent, while the core means by which the socialist city is unmade, or by means of which it lingers, is the reprivatization of urban property. Consequently, an anthropology of life in the socialist and postsocialist city is impoverished, if it does not - following the example set by anthropologists of the postsocialist countryside - foreground landed property and its social effects as an arena of investigation.

Developing this logic further, a Marxist understanding of political-economic infrastructure — as underlying and causally primary—becomes indispensable to the study of socialist urbanism and its aftermaths and legacies. Property relations, as Marx makes clear, are nothing "but a legal expression" of the "existing relations of production" (Marx and Engels [1868] 1970: 11). The study of property relations, and the morphological, aesthetic, spatial, and social effects they exert, in other words, is the closest thing anthropologists have to a royal road to a manageable comprehension of urban society, to a reduction of its complexity. The claim 
could, of course, be made that this is true for all research into urbanism and architecture, but this is beyond the scope of this article. Conversely, it could also be argued that there are equally useful non-Marxist approaches to property's social embeddedness, not least the Polanyian framework advocated by Chris Hann (1998). There are especially clear reasons, however, for deploying Marxist ideas in the anthropological study of socialism and of socialist cities - the sites on which, arguably, socialism as a political, ideological, and civilizational project witnessed its furthest-reaching realization.

On the terrain of the socialist city, the distinction between Marxist theory and socialist practice becomes blurred. Socialist cities were built and capitalist cities dismantled by Marxists, following, adjusting, reinterpreting, and implementing the Marxist critique of political economy. In this sense, socialist cities and buildings actually are Marxist: they are the Marxist critique of political economy planned and drawn on paper; rendered in stone, wood, glass, cement, and concrete; and filled with life, with living entities who were, by inhabiting and using these cities and buildings, engaged in the process of becoming socialist themselves. Here it is not merely the canonical works of Marx and Engels, which are relevant, but also what I have called, following Anna Kruglova (2018), the "vernacular" subvarieties of Marxism-Leninism, which constituted the official ideologies of socialist urbanism and provided the blueprint for the urban and architectural transformations - themselves framed, I show here, as really implemented reductions of the city's complexity - that socialism carried out. Consequently, in the form of the vernacular urban Marxisms that are operational in socialist and postsocialist cities, ethnographers have at their disposal valuable resources - not only expressed as theory, but actually built into the city, its buildings, and its social life — to develop emic understandings of their objects of study. ${ }^{7}$

The socialist city was created, thus, as a spectacularly literal implementation of Marx and 
Engels's highly illustrative phrase: "the theory of the communists can be summed up in one single sentence: the abolition of private property"8 ([1848] 1968: 47). Marx and Engels's phrase is both a theoretical principle and a normative, political recommendation - a recommendation that ideologues, decision makers, and architects of socialist urbanism set about implementing, in their various ways and to varying degrees of comprehensiveness and success. Accordingly, so can the ethnographers and theorists of the socialist and postsocialist city (the "Second World"

city) ${ }^{9}$ — who are possessed of methodological devices, which enable a complexity-reducing grasp of multiple dimensions of urban life, from the political and economic, to the spatial and aesthetic, the symbolic and affective-concentrate a great deal more scholarly energy than they have so far on making sense of the way in which private property was abolished, the ways in which it is currently being reinstantiated, and the effects and consequences of these proprietorial transformations.

\section{Keeping the palace vertical}

I illustrate my point about the causal architectonics of Warsaw-PKiN relations with a brief discussion of the palace-obsessed third series of Ekstradycja (Extradition; Wójcik 1999), the most popular crime series on Polish television during the 1990s. A nefarious alliance of former secret police officers (the ringleader, Tuwara), bent ministers, dodgy dignitaries, crooked Luxembourgish bankers of Polish extraction, and various other mafiosos meet in their rented lair, located on the fictional level minus three of the palace cellars. Pursuing the baddies is a triumvirate of incorruptible (but troubled) law enforcement functionaries (led by Lieutenant Halski), whose summits take place high in the clouds, on the PKiN's 30th floor viewing terrace. I devote a little room in the pages below to a description of some of the series' culminatory 
moments, as all of this article's key themes - morphological extremism (verticality versus

flatness), the reduction of complexity and political-economic determination founded on property relations—-are cast in starring roles.

\section{<<Figure 1 >>}

Figure 1: A still from the TV series Ekstradycja. Two members of the gangster consortium peer beneath a model of the Palace in their secret underground lair. Source: TVP.

The entire plot, in fact, is political-economic in the last instance. The dark characters are engaged in an evil scheme to gain control of Poland's gas and oil pipelines, motorways, financial system, government, the entire European continent, and so on. But they are most excited about their plan to purchase the Palace of Culture. The entire operation is revealed to have been hatched when Tuwara and his coconspirators attended an orphanage together (they affirmed their kin ties to each other by scrawling their names in blood on the back of a PKiN postcard). Minister of Foreign Affairs Osowski, who becomes deeply complicit in the group's dealings, is portrayed as a great enthusiast of the palace acquisition: as the project's potential financiers meet around a maquette of the palace, the minister, having constructed a smaller palace likeness from sugar cubes, points at his object of desire and exclaims: "Let's start with this! We have to have this!"

Getting hold of the terrain on which the palace stands, however, proves to be a stumbling block. In the words of the minster, "Gentlemen, you can't just procure the palace, as if it was some old shitter!" An assassin is thus hired to do away with those lawmakers who object to Tuwara's shadowy consortium acquiring the land rights to the building. Eventually, the 
government approves an exclusive lease for the PKiN to Tuwara and company (by this stage, everyone seems to have forgotten about the pipelines and motorways). By now, however, Lieutenant Halski and his band of celestial cops have figured out enough details to put an end to Tuwara's conspiracy. It also materializes that Tuwara himself may in fact be a GRU (Russian foreign intelligence) agent, but there's a twist: Sumar, the assassin, has beef with the "consortium" (they snitched on him after he completed his operation) and with Halski (who's on his tracks and whom Sumar lures into the palace by kidnapping his love interest). He also suspects that Tuwara is working for the Russians and happens to be the leader of a neofascist paramilitary organization, the "Real Patriots." Sumar's men steal 120 kilograms of Semtex from an army base, load it onto a train, park it at the (imaginary) secret Communist Party railway station in the underbelly of the palace, and attach a two-hour time delay fuse. This way, the assassin is multitasking: he prevents the takeover of "Polish national property" by—in the words of a warning he sends to a newspaper before the attack- "foreigners" and "Jews and postcommunists," therefore carrying out his ideological duty against the enemies of Poland; he is destroying the most blatant material testimony to its subordination, the Palace of Culture and Science; he is taking revenge on Tuwara; and he is covering his tracks by killing Halski.

Everything is set for this even-eviler plan to succeed: the worst-case scenario is that the combined collapse of the Palace and explosion in the railway tunnel will "take down a massive chunk of the city." But, at the last minute, a mute boy of about 10-who had been trapped in his mother's PKiN office overnight and over whose legs Halski had tripped in the building's lift lobby in a previous episode - finds the lieutenant dangling from a rope in the neo-Renaissance Gałczyński Hall on the palace's sixth floor, sets him free, and switches off the bomb's timer (with two seconds to go) by pressing the "enter" key on a laptop. Cheesy music plays as Halski 
and the boy emerge from the PKiN, bathed in dawn sunshine. Not only does the palace resist being flattened, but it also remains publicly owned.

The dynamics may be different, but the morphology of a construction site is rather similar to that of a landscape after a demolition or an explosion: everything is flat. During the 1980s and early 1990s, Polish popular and literary was replete with visions, which deployed the physical degeneration of the Palace - its destruction, degradation, or shrinking - as an allegory of the end of socialism itself. Visions of "flattening" the Palace articulated during the communist era, this goes to suggest, represented the building as codependent on the political economic regime, which erected it. The obdurate palace having outlived its guarantor system, any notions of demolishing it today (like former Minister of Foreign Affairs Radosław Sikorski's oftrepeated demand to knock the palace down and replace it with a park) tend to be represented by most people in Warsaw as pathological and anachronistic. At the same time, they are relegated into the domain of the impossible, first by reference to the "insane solidity" of the building's construction (these are the words of the Warsaw municipality's security chief) and second to its costliness and economic unfeasibility.

Impossible as it would be to actually flatten the palace, I argue that it would also be inaccurate and/or disingenuous to produce an account of Warsaw-PKiN relations, which keeps the social flat. Whichever part of the palace's social life is being looked at, political economies, cosmologies, eschatologies, and various other "aboves," "beyond," and "underneaths" come into view. Of all these "macros" and "infras," the political-economic domain is the last-instance determinant: a determination whose clearest and most consequential manifestation is the domain of property relations and in the attendant processes of expropriation and appropriation. ${ }^{10}$ 


\section{Deprivatizing the city: Reducing urban complexity}

How, then, does the morphology_or aesthetic — of a city where land is privately owned differ from one where it has been nationalized or communalized? How did state socialism reduce Warsaw's complexity, and how did complexity take over the city again following the socialist regime's fall in 1989? How did these dynamics make themselves evident within and around the Palace of Culture and Science?

Before 1945, the cadastral map of what was to be Parade Square was constituted by a dense thicket of landholdings, each of which corresponded to a privately owned tenement block (from four to six stories high). Already in 1935, Functional Warsaw, the bible of Warsaw's radical planners and architects before 1939, had sought to render coherent and integrated - in other words, to decomplexify — a "chaotic and atomized" city. In 1935, however, its authors lamented:

Nowadays, we know only too well, our proposal may seem purely utopian. As long as the city does not have at its disposal control over land ... its development will depend on the casual interest of the landowners. ... We are well aware that nowadays, when the socioeconomic conditions are far from satisfactory ones ... the only thing we can do is to prepare the theoretical premises for the Warsaw of the future. (Chmielewski and Syrkus 1935, cited in Malisz 1987: 261)

Less than a decade later, World War II was over; 70 to 80 percent of the city's built matter lay in ruins, and around half of its prewar population of 1.3 million lay dead (Sigalin 1986). But the consolidation of Soviet and communist hegemony in Eastern Europe ensured that, in an instant, 
the "socioeconomic conditions" that Jan Chmielewski and Szymon Syrkus dreamed of suddenly transpired. The "Warsaw of the future" could move from "theoretical premises" to real-life implementation.

\section{<<Figure 2〉>}

The Palace of Culture super-imposed onto an aerial photograph of central Warsaw from 1935. Copyright Google Maps.

$\langle<$ Figure 3>>

The Palace of Culture super-imposed onto an aerial photograph of central Warsaw from 1945. Copyright Google Maps.

\section{$<<$ Figure 4>>}

The Palace of Culture super-imposed onto a satellite image of central Warsaw from 2015. Copyright Google Maps.

Already in November 1944, Poland's Soviet-backed Provisional Government adopted a resolution outlining guidelines for the country's postwar reconstruction. One of its key postulates stipulated that the "building and development" of Poland's cities - and of Warsaw in particularwould require "a reform of urban land and property ownership ... restricting the rights of property owners" with the aim of "enabling the smooth implementation of urban planning 
intentions, facilitating and accelerating expropriation procedures and protecting against the socially damaging effects of landlord self-interest" (Sigalin 1986: 42). ${ }^{11}$ This postulate was expedited in October 1945, when postwar Poland's State National Council issued the Capital City of Warsaw Land Ownership and Use Decree, commonly known as the Bierut Decree, after then President of the Council (and de facto Polish Head of State) Bolesław Bierut. The Bierut Decree passed ownership of all landholdings within the prewar city limits, and de facto (though not de jure) most buildings standing on these plots as well, into the hands of the Warsaw municipality.

The decree constituted the legal expression of the new "socioeconomic conditions." It was the device that would allow the "chaotic and atomized" capitalist city—or what remained of it— to be rebuilt and transformed. Launching a six-year plan for rebuilding Warsaw in 1949, Bierut (1950)—by now Communist Party First Secretary—echoed Chmielewski and Syrkus's words of 15 years before, referring to "old Warsaw" as a "city of fragments, chaotically put together." The PKiN and Parade Square ensemble — early forms of which were announced as part of Bierut's plan - was to function as the pivotal component in the Communist Party-led effort to produce order and harmony from the chaos of the ruined old city. In the words of Syrkus, who keenly shifted from a modernist to a Stalinist architectural language after 1949, the palace was to be an "immovable guiding star on our journey to transform old Warsaw, princely Warsaw, royal, magnates', burghers', capitalist Warsaw into socialist Warsaw" (Sigalin 1986 460).

The palace and square were thus to constitute the clearest expression of the key condition of possibility behind the transformation of Warsaw: the reduction of the city's proprietary complexity. "On the rubble of the old city center," wrote Edmund Goldzamt, "The new Poland is raising its ceremonial forum—a great unified project covering a near 50-hectare space, constituted by an ensemble of buildings, parks, urban plaza interiors, all devoted to satisfying the 
life, leisure and cultural needs of man" (1956: 487).

\section{Postsocialist morphologies}

Fast-forward a little more than 30 years, to the fall of the Polish People's Republic in 1989. What impact has the unmaking of state socialism during the 1990s and 2000s had on Warsaw's urban morphology? And what were the consequences of this regime shift for the level of the palace's domination over Warsaw? What happened when the "total" city of socialism began to be unmade - and how does the reality of this unmaking compare to its metaphorical crystallization in the plot of Ekstradycja?

Beyond the aforementioned string of unrealized proposals to demolish the PKiN as an act of "catharsis," Warsaw's 1990s were marked by a multiplicity of Ekstradycja-like schemes to privatize the building and transform it into a profit-generating entity. Despite all this, both the physical body and public ownership status of the building itself have, so far, remained largely untampered with. Furthermore, the vast majority of the public functions constituting the palace as a "ceremonial forum" remain in place (despite regular rent hikes). ${ }^{12}$ Then, as now, the PKiN continues to play host to a variety of edifying cultural and educational institutions, including four theaters, a three-thousand-seat Congress Hall, the headquarters of the Polish Academy of Sciences, two universities, museums of technology and evolution, an art gallery, and an enormous Palace of Youth (which features a marble-clad swimming pool, among myriad other facilities), several cinemas, various nightclubs and restaurants, the city's primary radio and television broadcasting mast, municipal institutions, and a cloistered viewing terrace. Arguably, more so today than ever before, the palace exerts a prominent impact on Warsaw's popular and high culture, on its symbolic sphere and on various other facets of the city's everyday life. 
Almost 99 percent of Varsovians have been inside the PKiN; 61 percent of them consider it the city's primary symbol; 45 percent have a view of the building from their windows. ${ }^{13}$ Moreover, despite a slew of proposals to build a forest of skyscrapers and a tightly packed, moneymaking city center in its immediate vicinity, the PKiN is still the tallest building in Warsaw today. It continues to stand alone on Parade Square, a 25-hectare empty space devoid of any other permanent structures. The ideologues of the Stalinist 1950s had intended the palace to function as Warsaw's "territorial and vital center of gravity," its "architectural power distributed throughout the city as a whole" (Goldzamt 1956: 202). And today—a quarter century after communism — the palace continues to pervade and dominate the city, just as its Stalin-era designers intended it to.

While the new order has so far been unable to successfully interfere with the centrality, verticality, and publicness of the palace itself, the ground-level postsocialist trajectory of Parade Square has been considerably more discombobulating. For more than four decades after the completion of the PKiN's construction in July 1955, the square remained an essentially open, well-ordered space: in parts austere and windswept, in others functional and throbbing with commuters, or green and leisurely, landscaped with trees, grass, and fountains. Around the middle of 1989, however - just as the first (semi-)free elections to the Polish parliament were being held - wild capitalism acquired instant material expression in the form of the Parade Square bazaar .

Legal, semilegal, or illegal street trade on the territory of Parade Square continued to occur, in various guises, for almost two decades: first from plastic sheets laid out on the ground, then from temporary iron or plastic booths, and finally from giant, corrugated iron hangars placed in the square by the municipality during the 1990s. During this time, the condition of 
Parade Square slowly degenerated. The flowerbeds were trampled; the granite mosaics and brass sundials set into the ground were crushed or haphazardly dismantled. Of course, the traders' presence on the square was always conceived of as temporary, and their eventual removal from the square in 2009 — when the last of three market hangars was finally demolished — resulted in a regular riot. Police equipped with water cannon, horses, and tear gas and backed up by truncheon-wielding private security guards staged running battles against a several-hundred strong group of traders barricaded inside.

The traders' cleansing from the square was intended to make way for two crucial investments: the Museum of Modern Art, the first plank of the city's master plan to "civilize" the palace's surroundings; and the key, interchange station of the second line of Warsaw's underground railway system. While the second project was completed in summer 2015, the Museum of Modern Art — and the whole Parade Square master plan — has yet to move off the drawing board. The contract between the city, the museum, and the Swiss architect who won a controversy-laden competition for the project in 2007 was severed in May 2012. Christian Kerez, the architect, and much of the press cited the city's inability to resolve the age-old question of property restitution claims on the proposed Museum site as the chief reason for the city's withdrawal from the project. I am moving toward the suggestion that the post-1989 fortunes of Parade Square-morphological, aesthetic, functional, and otherwise — simply constituted an expression of a much bigger question: that of the property regimes shifting underfoot. Whereas the municipality continues to own the palace itself, the status of the land on which it stands, and especially of the surrounding plots - those expropriated from their former owners by the 1945 Bierut Decree_-is far less clear. 


\section{Fuzzy property restitution in Warsaw: "Bloody complicated"}

In her work on property restitution in rural Romania, Katherine Verdery emphasizes the diversity, complexity, and ambiguity of postsocialist property regimes, which cannot be defined according to any set of universal principles. "Each case has its specificity," writes Verdery (2003: ix), and the legal "disambiguation" of property rights (especially toward private ownership) is not necessarily of benefit to all those involved. "For villagers who lack the resources to convert ownership of a plot into yield, a system of overlapping claims and rights provides a far more satisfactory ownership arrangement than would exclusive or individual ones" (1998: 179). In the context of an emerging neoliberal property regime, in Verdery's opinion, the maintenance of a "fuzzy" arrangement is sometimes more equitable and beneficial to the majority than is its simplification.

In a related vein, the urban sociologist Joanna Kusiak argues, with reference to Parade Square, that the top-down elimination of "chaos" does not always produce the desired effect (“order"). "Whenever we hear the word 'chaos,' we should thoroughly search the pockets of order," writes Kusiak (2012: 307), arguing that the case of Warsaw brings home the extent to which these two terms are inextricably intertwined. While fully accepting that a pure iteration of either chaos or order, complexity or simplicity, communism or capitalism is chimerical, and that both possess complex, in David Stark's (1996) term "recombinant" forms, I do not focus here on problematizing binaries or blurring boundaries between notions of public and private property. Instead, I would like to show how the particular form of proprietorial fuzziness afflicting postsocialist Warsaw is currently producing a situation, where the exploitation of the dispossessed by the propertied and the degradation of public space proceeds unchecked.

It is helpful to draw on Verdery's instructive characterization of property as a "total 
system of social, cultural and political relations" (1999: 54). As she puts it elsewhere, property is “about everything: power, practices, institutions, land, the transformation of value, social relations, privatization, class formation, and so on" (2003: 32). Especially when it comes to questions of architecture, urban design, and city building, property is, literally, a foundational concern, on whose ground the totality of attendant social relations condenses. What is at stake, then, is not just the question of "who literally owns" the land on Parade Square itself but the entire complex of social relations triggered by the broader Parade Square property regime.

But Warsaw is very different to Verdery's rural Romania. In the Polish capital, it is precisely the fuzziness of property that constitutes a dramatic barrier to social and spatial justice. Unlike in most other formerly communist countries - with the exception of most of the non-EU post-Soviet states, where very little restitution (as opposed to privatization) has happened at all— no comprehensive Poland-wide property restitution (reprywatyzacja in Polish, literally “reprivatization”) law has been passed since 1989 (see Marcuse 1996). This means that the passage through the courts of every single property restitution claim relies on a treacherous medley of precedents, partial restitution bills (such as a 1997 law covering the return of religious communal properties) local bylaws and leftover legislation from the socialist era — not to speak of changing political and financial "pressures" and "incentives" exerted by administrators, developers, and other interested parties.

The lack of any overarching legal framework for restitution since 1989 has meant, then, that landholdings could only be returned to their prewar owners (or their descendants or, more often than not, property speculators who purchased their appeals from the owners' descendants at a knockdown price) on the basis of the Bierut Decree, provided they had registered an appeal with the authorities within six months of their plot being initially confiscated. In other words, 
you can only get your property back thanks to the continued existence of the very same law that expropriated it in the first place.

Several thousand decree properties have been returned since 1989 in a process known as "small restitution" (mała reprywatyzacja). The Palace of Culture and Science and its immediate vicinity, however, were resistant to restitution until quite recently, with myriad reasons cited for this state of affairs, among them being the total lack of correspondence between the shape and position of the prewar, current, and planned future land plots (former Mayor Paweł Piskorski tended to refer to this as a "mosaic," whereas current Mayor Hanna Gronkiewicz-Waltz prefers the term "confetti"); the cross-contestation of some claims between feuding family members distributed around the world and property speculators; the extremely high value of land on Parade Square, whose centrality and excellent transport infrastructure makes these the most expensive parcels in Warsaw; the enormous size of the square, which magnifies all the above factors; and the "rotten" and rubble-infested condition of the infrastructure beneath the square. What is more, a substantial proportion of the plots, especially in the northern section of Parade Square, belonged to Jewish Varsovians, who constituted the majority population in this area of the city center. Almost the entirety of Warsaw's Jews was either murdered during the Holocaust or were not present in 1945 and therefore unable to launch an appeal against the Bierut Decree, a necessary condition for restitution today (these plots therefore constitute the bulk of those classified as "heirless"). Right-wing politicians often invoke the specter of returning Jewish landowners as a reason to maintain the continuing "property fuzz" on Parade Square.

When I asked Piskorski, an economic liberal and restitution enthusiast who returned around one thousand plots during his term in office (1998-2000), what was it was that made Parade Square so untouchable, he spread his arms and said: "I just couldn't touch it! Maybe if I 
had finished my term I could have done, but this place was just a different story altogether. It was so bloody complicated" (the Ekstradycja baddies, it is worth recalling, were unable to procure ownership of the PKiN and its surroundings without engaging the services of an assassin).

The floodgates for Parade Square restitution were opened in 2008, however, when the businessman Tadeusz Koss - the elderly grandson of an aristocratic tenement block landlord— became the first private owner of a Parade Square property plot. Having regained ownership after almost two decades of litigation, lobbying, and — as he openly admitted to me — bribery, he has been able to do very little other than "sit on a chair and revel in my ownership rights." A public park occupies most of the parcel in his name, while another section has had the entrance to a new Metro station built on it. In frustration, Koss eventually leased his corner of the park to a marketing firm, which used it to erect an enormous billboard that obscured the view onto the park from the street. It stood for several months before being disassembled after the municipality was able to demonstrate that it fell foul of the binding local plan. Koss has subsequently been able to get around the ban by having the firm to whom he leases the plot sublease it in turn to other firms, who periodically erect advertising hoardings and other dubiously legal structures there-most recently, in the summer of 2017, a decommissioned airplane housing a fast food restaurant - which stand for as long as they can before the municipality is able to intervene.

In the opinion of many Varsovians, the unresolved specter of the Bierut Decree ultimately constitutes the most important determinant behind the spatial "chaos" plaguing Parade Square - and beyond that, Warsaw as a whole. The Social Democrat Marek Balicki, a mayoral candidate in 2002, answered me without hesitation: "The unregulated ownership situation is the key thing. Here the state has failed to deliver." "This should be regulated by law, and that's that. 
Just like it was regulated in part after the war," he continued, responding enthusiastically to the expropriatory Bierut Decree as a model to emulate. "Maintaining this state of uncertainty is advantageous only for speculation and for speculators." For Balicki, property restitution "should have a fairly limited character. Property rights are not always more important than other things. [Private] property is not a sacred, inalienable right. But this is how it is treated in Poland, and that's why this is all unregulated by law." Piskorski has an utterly divergent understanding of private property to Balicki, yet his position is symmetrical. "If there had only been a restitution law" in place during his term as mayor, said Piskorski, the situation would already have been resolved by now. This new law could take any form, as long as it was clear and decisive: "returning the plots to their owners, offering the compensation, or even stripping them of their ownership rights altogether, whatever. If this had been in place, we could have out together a consortium [to sort this out], even during my first term as mayor."

\section{Fuzzy infrastructural violence}

Just as the PKiN and Parade Square continue to constitute postsocialist Warsaw's "territorial and vital center of gravity" (Goldzamt 1956: 22), so do the tensions and complexities of the city's present proprietary morass manifest themselves there with exaggerated clarity. But the casualties of complexity are distributed throughout the city: public institutions-including some of the country's most treasured museums and universities — and even municipal or government offices in central Warsaw located within former aristocratic palaces are frequently turfed out, even if the buildings within which they are housed were destroyed during the war and rebuilt at the cost of the state. 2013 and 2014 saw the closures of a spate of schools, raised during the 1950s and 1960s on land that has since been reclaimed by a prewar property heir or speculator. 
The coercive effects of property reprivatization take their most drastic form in situations involving conflicts between tenants and private landlords. Regular illegal evictions and demolitions take place in Warsaw, while landlords or speculators - the beneficiaries of restitution - frequently allow the tenement blocks they own to fall into disrepair, in an effort to bypass tenant protection laws and force inhabitants to move out. What's more, several fires of tenement blocks — which had been turned into communal housing in the 1940s and 1950s and were recently restituted - have also been linked to landlord foul play. On 1 March 2011, the charred remains of Jolanta Brzeska, a well-known tenants' activist, were found in a forest in the Warsaw suburbs. The investigation into her death has been fruitless so far, but many in Warsaw are convinced that Brzeska was murdered because of her work.

Dennis Rodgers and Bruce O’Neill's category of “infrastructural violence” seeks to pinpoint "when it is that infrastructure becomes violent, for whom, under what conditions and why" (2012: 402). Rodgers and O’Neill—who use "infrastructure" to refer to the strictly tangible "buildings, wires, pipes, roadways, cemeteries, and so on"-_istinguish between "active" and "passive" infrastructural violence. The chaotic, coercive dynamics of property reprivatization in postsocialist Warsaw, however, suggest a third category: "fuzzy" infrastructural violence, or “infrastructural violence by complexity." For Verdery, the ambiguous, ill-defined nature of postsocialist property arrangements — their "reticular and rhizomatic" (2003: 72) character—has the effect of protecting villagers against some of the harmful effects of privatization. ${ }^{14}$ In Warsaw, by contrast, it is precisely an ill-codified, fuzzy system of "overlapping rights and claims" (1998: 179) that works to the violent, sometimes murderous detriment of those dispossessed by the new regime and exerts a privative, stratifying impact on the on the quality of Warsaw’s public space. 
Having been downplayed in the press and by politicians for years, the "wild restitution" (dzika reprywatyzacja) affair erupted into a full-on political scandal in 2016, after several years of tireless work by a snowballing group of activists and journalists finally saw fruition. The farreaching, devastating nature of fuzzy property's assault on Varsovians' lives and Warsaw's social and urban fabric, as well as the vast network of elite corruption underlying it, led many commentators to refer to the restitution affair as the biggest political scandal in the history of the Third Republic (the official name for the post-1989 Polish state). Among its many ingredients were confirmation of the long-denied allegation that the mayor's own husband had acquired part ownership of an apartment block confiscated from its murdered Jewish owner by the Nazis during World War II (Koss told me back in 2010: "He bought the claim! And she 'sorted it out the details.' . . I'm keeping this [evidence] up my sleeve"); the staggered dismissal by the mayor of several senior officials (among them her deputy) accused of forming a "restitution mafia" in cahoots with property speculators; and the revelation that a speculator linked to this mafia had illegally obtained a Parade Square land plot valued at $€ 40$ million (160 million złoty). Poland's new welfarist-conservative government, elected in 2015 , has sought to pin the blame for wild restitution entirely on the opposition Civic Platform (Gronkiewicz-Waltz's party), who ruled Poland from 2007 to 2015 and still runs Warsaw.

After much political tussling, Polish President Andrzej Duda eventually approved a Warsaw-specific "minor" restitution bill in August 2016 (which Mayor Gronkiewicz-Waltz had been promising to implement since 2012), whose purpose was to temper speculation on restitutable property by regulating the buying and selling of property claims and granting the public purse the right to buy property claims, without having to return them first (this clause would have saved the municipality a huge sum had it been implemented several years previously) 
and the right to refuse the return of war-damaged property rebuilt by the state. The new law, however, still leaves many questions unanswered, and loose ends untied. Although evictions have slowed since the law came into force in September, no guilty parties have been prosecuted, very few illegally restituted properties have returned to public ownership, and tenants' rights remain without substantive formal protection. The major political parties are continuing to tussle over the details of a promised "major" restitution bill (Warsaw-specific or nationwide), which would supersede the August 2016 law. The Law and Justice party, meanwhile (possibly realizing the extent of their lawmakers' own implication in the scandal) have mysteriously stopped raising the issue of restitution in their condemnation of Civic Platform, while the Civic Platform-ran Warsaw municipality has canceled a planned independent audit of the restitution affair. Although "wild" restitution in Warsaw itself has temporarily been tempered, all major parties on both sides of the barricade remain united on one matter: their continued declared commitment to the "historical justice" of property restitution.

\section{Conclusion: The concrete diversity of infrastructure}

The complexity-embracing landscapes of the late capitalist city and the complexifying epistemologies (and metaphors) of the (still) postmodern academy do not constitute unconnected phenomena. ${ }^{4}$ Just as Warsaw is in dire need of a de-fuzzing of property rights, so too would the terrain of anthropological knowledge benefit from a reconfiguration of its morphological imaginary. Many scholars today, however-especially those of a flattening or complexifying persuasion - are wont to emphasize how their presentations and understandings of the world are resistant to totalizing vulgarizations, irreducible to any macro contexts, especially those of a political-economic ilk. I have tried, in this article, to counter this illusion of autonomy by 
insinuating a connection between the chaotic, deregulated morphologies and dynamics of the late capitalist city, and the morphological imaginaries, which populate the early twenty-first century intellectual landscape.

Today's late capitalist academy and city, however, are a little like Chmielewski and Syrkus's Warsaw of 1935 (or Gronkiewicz-Waltz's of 2017). There does not, at first glance, seem to be any fundamental sort of shape-shifting (or proprietorial redistribution) on the horizon. So what posture should thinkers driven by critical, radical, or contrarian motivations adopt, while we await the coming of academia's own Bierut Decree?

As Jonathan Friedman's observations — cited in the opening section of this articlesuggest, the "complexification" of social life is a process integrally linked to the rise, consolidation, and refinement of the capitalist political economy in its successive incarnations. In Maurice Godelier's words, the capitalist mode of production, “far more than any others, separated economics, politics, religion, kinship, art, etc., into so many different institutions." For Godelier, the distinct advantage of a Marxist ethnographic sensitivity is an awareness of the dialectical coconstitution of processes of rupture and fragmentation with those of fixity and fragility. Marxism is not "some sort of empiricism" that conflates appearances and essences; nevertheless, "of all theoretical approaches it is assuredly the one that is obliged to submit itself most thoroughly to the concrete diversity of experience" (1978: 765)

This brings me to the relationship between Godelier's understanding of infrastructure and materiality. To discern the "distinction between infrastructure, superstructure and ideology" does not, he emphasizes, involve adjudicating between the physicality and non-physicality of a thing or an institution, of an object or a social fact. The domains of thought and language, Godelier points out, may function not only as elements of society's ideological superstructure but also as 
"components of the infrastructure, as part of a society's forces of production." For Godelier, the distinction is "not between material and immaterial, for I fail to see in what way thought could be less material than the rest of social life. Nor is it a distinction between tangible and intangible. It is a distinction of position within those activities necessary to the reproduction of social life" (764).

If thought and language can form part of the infrastructure as much as part of the superstructure, then, it follows that infrastructure - understood purely in terms of its "brute materiality," as "walls, pipes, wires and roads" — can also function as part of the superstructure. To return to Rodgers and O'Neill's (2012) category of "infrastructural violence," if an ethnographer wants to understand how a wall is implicated in processes of social coercion or exploitation, they will not get far purely by discerning that it is made up of a multiplicity of red, roughly textured bricks, which constitute an impediment to physical movement. In order to shed light on the wall's role in processes of infrastructural violence, the ethnographer would have to figure out whose idea it was to build it, whom it divides from whom, who paid for it (or, as the case may be, who forced whom to pay for it), whom it hurts, and whom it benefits—and many other things that take us far beyond a concern with brute materiality or irreducible plurality. If, as materialists, we do not want to reduce infrastructure to superstructure, we must look above, beyond, and beneath infrastructure's materiality.

For Godelier, a materialist anthropology consists of an inquiry into and critique of the "locus and form of a society's economy" or a "topology of economics- the comparative topology of relations of production" $(1978: 765,764)$. Materialist anthropology is thus a form of inquiry that occupies itself with discerning the size, shape, and location not merely of tangible things but also of the relationships, causalities, and dependencies, which link them ${ }^{15}$ and endow 
them with differential positions with regard to their impact on the productive process. It is worth comparing, from this point of view, Godelier's materialist "economic topology" with the Durkheimian-Maussian notion of "social morphology" (from which this article borrows its title) - the branch of the study of society pertaining to the "tangible, material forms of societies" (Durkheim 1978: 99). In Émile Durkheim's characterization, social morphology entails a vertical, causal understanding of society, encompassing the study of the "social substratum ... determinate both in its extent and its form," its constitution "directly or indirectly" affecting "all social phenomena, just as psychic phenomena are placed in mediate or immediate relationship with the brain."

What distinguishes the kernel of materialism from the shell of Durkheimian social morphology, however, is the former's foregrounding not merely of the tangibility of physical forms, nor of their causal location within a determinate substratum, but of their role within the social relations of production. Marxist morphologies do not merely have to be vertical, nor concerned with materiality: they also, in the last analysis, ought to be materialist.

Michał Murawski is an anthropologist of architecture. He is Leverhulme Fellow in the School of Slavonic and Eastern European Studies, University College London and received his $\mathrm{PhD}$ from the University of Cambridge in 2014. His publications include the forthcoming Palace Complex: A Stalinist Skyscraper, Capitalist Warsaw and a City Transfixed (Indiana University Press, 2018) and (coedited with Jane Rendell), “A Century of the Social Condenser, 19172017," a special issue of The Journal of Architecture (2017). His current book project focuses on architectural aesthetics and municipal politics in Putin-era Moscow. Email: g.m.murawski@gmail.com 


\section{References}

Althusser, Louis. 1969. For Marx. London: Allen Lane.

Althusser, Louis. 1971. Lenin and philosophy, and other essays. London: New Left Books.

Anderson, Jane, and Haidy Geismar. 2017. The Routledge companion to cultural property. London: Routledge.

Bierut, Boleslaw. 1950. Szescioletni plan odbudowy Warszawy [Six-year plan to build Warsaw]. Warszawa: Ksiazka i Wiedza.

Bocharnikova, Daria, and Steven E. Harris. 2018. "Second world urbanity: Infrastructures of utopia and really existing socialism.” Journal of Urban History 44 (1): 3-8.

Boyer, Dominic. 2014. “Dominic Boyer on the anthropology of infrastructure.” Platypus, 3 May. http://blog.castac.org/2014/03/dominic-boyer-on-the-anthropology-of-infrastructure.

Brenner, Neil, David J. Madden, and David Wachsmuth. 2011. "Assemblage urbanism and the challenges of critical urban theory." City 15 (2): 225-240.

Buchowski, Michał. 2006. "Property relations and social identity in rural Poland.” Max Planck Institute for Social Anthropology Working Paper No. 83.

Carsten, Janet, and Stephen Hugh-Jones, eds. 1995. About the house: Lévi-Strauss and beyond. Cambridge: Cambridge University Press.

Certeau, Michel de. 1984. The practice of everyday life. Berkeley: University of California Press. Chelcea, Liviu. 2006. "Gentrification, property rights and post-socialist primitive accumulation (Bucharest, Romania)." In Social changes and social sustainability in historical urban centres: The case of Central Europe, ed. György Enyedi and Zoltan Kovacs Pecs, 120126. Budapest: Centre for Regional Studies of the Hungarian Academy of Sciences. 
Chmielewski, Jan, and Szymon Syrkus. 1935. Warszawa funkcjonalna: Przyczynek do urbanizacji regjonu Warszawskiego [Functional Warsaw: A contribution to the urbanization of the Warsaw regency]. Warszawa: SARP.

Comaroff, John L., and Jean Comaroff 1998. "Reflections on the colonial state, in South Africa and elsewhere: Factions, fragments, facts and fictions." Social Identities 4 (3): 321-361.

Corsin-Jimenez, Alberto. 2010. "The height, length and width of social theory." In The social after Gabriel Tarde: Debates and assessments, ed. Matei Candea, 111-129. London: Routledge.

Dan-Cohen, Talia. 2017. "Epistemic artefacts: On the uses of complexity in anthropology." Journal of the Royal Anthropological Institute 23 (2): 285-301.

Dunn, Elizabeth, and Katherine Verdery. 2011. "Dead ends in the critique of (post)socialist anthropology: Reply to Thelen.” Critique of Anthropology 31 (3): 251-255.

Durkheim, Emile. 1978. Emile Durkheim on institutional analysis. Chicago: University of Chicago Press.

Farías, Ignacio. 2011. "The politics of urban assemblages.” City 15 (3-4): 365-374.

Fay, Derick, and Deborah James. 2008. “"Restoring what was ours': An introduction.” In The rights and wrongs of land restitution: "Restoring what was ours," ed. Derick Fay and Deborah James, 1-29. London: Routledge.

Ferguson, James. 2012. "Structures of responsibility.” Ethnography 13 (4): 558-562.

Friedman, Jonathan. 1993. "Order and disorder in global systems: A sketch.” Social Research 60 (2): 205-234.

Godelier, Maurice. 1978. "Infrastructures, societies and history." Current Anthropology: A World Journal of the Sciences of Man 19 (4): 763-771. 
Goldzamt, Edmund. 1956. Architektura zespolów sródmiejskich i problemy dziedzictwa [Architectures of city complexes and heritage problems]. Warszawa: Panstwowe Wydawn. Naukowe.

graham, Stephen, and Lucy Hewitt. 2013. "Getting off the ground: On the politics of urban verticality." Progress in Human Geography 37 (1): 72-92.

Halawa, Mateusz. 2015. "In New Warsaw: Mortgage credit and the unfolding of space and time." Cultural Studies 29 (5-6): 707-732.

Hann, Chris. 1998. "Introduction: The embededdness of property." In Property relations: Renewing the anthropological tradition, ed. Chris Hann, 1-47. Cambridge: Cambridge University Press.

Hann, Chris, ed. 2005. Property relations: The Halle focus group. Halle/Saale: Max Planck Institute for Social Anthropology.

Harris, Andrew. 2015. "Vertical urbanisms: Opening up geographies of the three-dimensional city." Progress in Human Geography 39 (5): 601-620.

Harvey, Penelope. 2012. "The topological quality of infrastructural relation: An ethnographic approach." Theory, Culture and Society 29 (4-5): 76-92.

Holbraad, Martin. 2017. "Shapes of Relations: Steps to a new social morphology.” Inaugural lecture delivered at University College London, 21 February.

Humphrey, Caroline. 1998. Marx went away—but Karl stayed behind. Ann Arbor: University of Michigan Press.

Humphrey, Caroline. 2007. "New subjects and situated interdependence: After privatisation in the city of Ulan Ude." In Urban life in post-soviet Asia, ed. Catherine Alexander, Victor Buchli, and Caroline Humphrey, 175-207. London: University College London Press. 
James, Deborah. 2007. Gaining ground: "Rights" and "property" in South African land reform. London: Routledge-Cavendish.

Kaneff, Deema. 1998. “When 'land' becomes 'territory': Land privatisation and ethnicity in rural Bulgaria.” In Surviving post-socialism: Local strategies and regional responses in Eastern Europe and the former Soviet Union, ed. Susan Bridger and Francis Pine, 16-32. London: Routledge.

Kaneff, Deema, and Alexander D. King. 2004. "Introduction: Owning culture.” FocaalEuropean Journal of Anthropology 44: 3-19.

Karatani, Kojin. 2008. “Beyond capital-nation-state.” Rethinking Marxism 20 (4): 569-595.

Kruglova, Anna. 2018. "Social Theory and Everyday Marxists: Political economies of material effect in the recursive view." Comparative Studies in Society and History 59 (4): 759785.

Kusiak, Joanna. 2012. "The cunning of chaos and its orders: A taxonomy of urban chaos in postsocialist Warsaw." In Chasing Warsaw: Socio-material dynamics of urban change since 1990, ed. Monika Grubbauer and Joanna Kusiak, 291-321. Frankfurt: Campus Verlag.

Larkin, Brian. 2013. "The politics and poetics of infrastructure." Annual Review of Anthropology 42: $327-343$

Latour, Bruno. 2005. Reassembling the social: An introduction to actor-network-theory. Oxford: Oxford University Press.

Latour, Bruno. 2006. Paris: Invisible city. Paris: La Découverte.

Leach, Edmund Ronald. 1984. "Glimpses of the unmentionable in the history of British social anthropology." Annual Review of Anthropology 13: 1-23.

Lévi-Strauss, Claude. 1969. The elementary structures of kinship. Boston: Beacon Press. 
Malisz, Boleslaw. 1987. "Functional Warsaw: A challenge from the past." Planning Perspectives 2 (3): 254-269.

Marcuse, Peter. 1996. "Privatization and its discontents: Property rights in land and housing in the transition in Eastern Europe." In Cities after socialism: Urban and regional change and conflict in post-socialist societies, ed. Gregoly Andrusz, Michael Harloe, and Ivan Szelenyi, 119-191. Cambridge: Blackwell.

Marx, Karl. 1970. A contribution to the critique of political economy. New York: International Publishers.

Marx, Karl, and Friedrich Engels. (1848) 1968. Karl Marx and Frederick Engels: Selected works in one volume. New York: International Publishers.

Mattioli, Fabio. 2016. "Losing values: Illiquidity, personhood, and the return of authoritarianism in Skopje, Macedonia.” PhD diss., City University of New York.

McFarlane, Colin. 2011. “The city as assemblage: Dwelling and urban space.” Environment and Planning D: Society and Space 29 (4): 649-671.

Murawski, Michał. 2013. "Palaceology, or palace-as-methodology: Ethnographic conceptualism, total urbanism and a Stalinist skyscraper in Warsaw." Laboratorium: Russian Review of Social Science 5 (2): 56-83.

Murawski, Michał. 2016. 'Big affects: Sex, size and Stalinist 'architectural power' in postsocialist Warsaw.” In Elements of architecture: Assembling archaeology, atmosphere and the performance of building space, ed. Mikkel Bille and Tim Flohr Sorenson, 63-83. London: Routledge.

Murawski, Michał. 2017a. "Radical centres: The politics of monumentality in 21 st century Warsaw and Johannesburg." Third Text: Critical Perspectives on Contemporary Art and 
Culture, published online 7 March.

Murawski, Michał. 2017b. "Introduction: Crystallising the social condenser." Journal of Architecture 22 (3): 372-386.

Murawski, Michał. 2017c. "A Stalinist social condenser in a capitalist city.” Journal of Architecture 22 (3): 458-477.

Murawski, Michał. 2018. "Actually-existing success: Economics, aesthetics and a still-socialist skyscraper in capitalist Warsaw." Comparative Studies in Society and History 60 (4).

Murawski, Michał. Forthcoming. Palace complex. Bloomington: Indiana University Press.

Neveling, Patrick. 2014. "Three shades of embeddedness, state capitalism as the informal economy, emic notions of the anti-market, and counterfeit garments in the Mauritian export processing zone." In Production, consumption, business and the economy: Structural ideals and moral realities, ed. Donald C. Wood, 65-94. Bingley: Emerald Group Publishing.

Neveling, Patrick, and Carsten Wergin. 2009. "Projects of scale-making: New perspectives for the anthropology of tourism." Etn Etnográfica 13 (2): 315-342.

Ong, Aihwa. 2011. "Introduction: Worlding cities, or the art of being global." In Worlding cities: Asian experiments and the art of being global. ed. Aihwa Ong and Ananya Roy, 1-26. Cambridge: Blackwell.

Parry, Bronwyn. 2004. Trading the genome: Investigating the commodification of bioinformation. New York: Columbia University Press.

Peacock, Vita. 2015. "The negation of hierarchy and its consequences." Anthropological Theory $15(1): 3-21$.

Rodgers, Dennis, and Bruce O'Neill. 2012. "Infrastructural violence: Introduction to the special 
issue." Ethnography 13 (4): 401-412.

Sigalin, Józef. 1986 Warszawa 1944-1980: Z archiwum architekta [Warsaw 1944-1980: From the archives of the architect]. 3 vols. Warszawa: Panstwowy Instytut Wydawniczy.

Sikor, Thomas, Stefan Dorondel, Johannes Stahl, and Phuc Xuan To. 2017. When things become property: Land reform, authority and value in postsocialist Europe and Asia. New York: Berghahn Books.

Simone, AbdouMaliq. 2012. "Infrastructure: Introductory commentary." Cultural Anthropology, 26 November. http://www.culanth.org/curated_collections/11infrastructure/discussions/12-infrastructure-introductory-commentary-by-abdoumaliqsimone.

Ssorin-Chaikov, Nikolai V. "Introduction: Notes on ethnographic conceptualism." Laboratorium: Russian Review of Social Research 5 (2): 5-18.

Stark, David. 1996. "Recombinant property in East European capitalism." American Journal of Sociology 101 (4): 993-1027.

Strathern, Marilyn. 1999. Property, substance, and effect: Anthropological essays on persons and things. London: Athlone Press.

Tsing, Anna. 2000. “The global situation.” Cultural Anthropology 15 (3): 327-360.

Verdery, Katherine. 1998. "Property and power in Transylvania's decollectivization.” In Property relations: Renewing the anthropological tradition, ed. Chris Hann, 160-180. Cambridge: Cambridge University Press.

Verdery, Katherine. 1999. "Fuzzy property rights: Power and identity in Transylvania's Decollectivization." In Uncertain transition: Ethnographies of change in the postsocialist world, ed. Katherine Verdery and Michael Burawoy, 63-83. Oxford: Rowman \& 
Littlefield.

Verdery, Katherine. 2003. The vanishing hectare: Property and value in postsocialist

Transylvania. Ithaca, NY: Cornell University Press.

Verdery, Katherine, and Caroline Humphrey. 2004. Property in question: Value transformation in the global economy. London: Bloomsbury Academic.

Wójcik, Wojciech. 1999. Ekstradycja 3 [Extradition 3]. Television series. Warsaw: TVP

Zerilli, Filippo M. 2010. “The rule of soft law: An introduction.” Focaal_Journal of Global and Historical Anthropology 56: 3-1

\section{Notes}

${ }^{1}$ For a preliminary theorization of social and political morphology, see Murawski (2017a); Holbraad (2017) has also recently discussed social morphology.

${ }^{2}$ My discussion is, in part, informed by two linked debates among cities scholars: one on the pitfalls of "assemblage urbanism," conducted largely on the pages of City (Brenner et al. 2011; Farías 2011; McFarlane 2011) — my position overlaps with Brenner and colleagues' (2011) critique of the asssemblagist tendency to shy away from political economy; and another discussion on the need for a new empirical sensitivity to "verticality" in geography and urban studies (see Graham and Hewitt 2013; Harris 2015). I expand on the "microphiliac" "ideologies of scale" (Neveling 2014; Neveling and Wergin 2009; Tsing 2000) associated with the notion of "assemblage" in Murawski (2016).

${ }^{3}$ Architectural metaphors constitute an ancient sub-genre of intellectual and religious thought, but they are particularly frequently encountered - as scholars have pointed out, in the work of 19th and twentieth century social theorists (Althusser 1971 and Marx 1970 have been 
reconsidered by Carsten and Hugh-Jones 1995; Karatani 2008; Lévi-Strauss 1969).

${ }^{4}$ I develop the idea of "still-socialism" (as opposed to "postsocialism") in Murawski (2018).

${ }^{5}$ I am indebted to an anonymous reviewer from Focaal for a series of extremely insightful remarks, which helped me to clarify my thoughts on the relationship between anthropological scholarship on property and complexity, the marginalization of Marxism in anthropology, and the global systemic “disjunctures”- to use Deborah James's phrase (2007) —of the late twentieth and early twenty-first century.

${ }^{6}$ Existing work on urban property restitution, reprivatization, and mortgaging in Eastern Europe includes Chelcea (2006); Halawa (2015); Humphrey (2007); Kusiak (2012); Marcuse (1996); Mattioli (2016); Stark (1996); Zerilli (2010).

${ }^{7}$ I elaborate on the relationship between "emic" and "vernacular" urban Marxisms in Murawski (2018).

${ }^{8}$ Katherine Verdery (2003: 48) briefly makes a related point about the centrality of Marx-derived notions of property to social and institutional life in state socialist societies.

9 For an extrapolation of the notion of "Second World" urbanity, see Bocharnikova and Harris (2017).

${ }^{10}$ I provide a more detailed account of the "Palace complex" in still-socialist Warsaw in Murawski (forthcoming).

${ }^{11}$ All translations are my own unless otherwise indicated.

${ }^{12}$ In Murawski (2017b, 2017c), I describe the way in which this multiplicity of publicly owned functions allows the Palace to function as a constructivist "social condenser" — an architectural generator of collective social relations - in capitalist Warsaw.

${ }^{13}$ In October 2010, I carried out an online questionnaire, composed of 70 questions about the 
Palace's relationship with Warsaw (see Murawski 2013).

${ }^{14}$ See, however, Dunn and Verdery's (2011) important defense of political economy as a category through which to view the postsocialist transition.

${ }^{15}$ For a related series of reflections on this topic, see Alberto Corsin-Jimenez's (2010) reflections on the "height, length, and width" of social theory. 